\title{
Maitotilan fosfori- ja typpikierron mallintaminen
}

\author{
Juha Nousiainen $^{1)}$, Mikko, Tuori ${ }^{2)}$, Eila Turtola ${ }^{3)}$ ja Pekka Huhtanen ${ }^{2,4)}$ \\ ${ }^{1)}$ Valio Oy, Alkutuotanto, PL 10, 00039 Valio, etunimi.sukunimi@valio.fi \\ ${ }^{2}$ MTT, Kotieläintuotannon tutkimus, 31600 Jokioinen, etunimi.sukunimi@mtt.fi \\ ${ }^{2)}$ MTT, Kasvintuotannon tutkimus, 31600 Jokioinen, 31600 Jokioinen, etunimi.sukunimi@mtt.fi \\ ${ }^{4)}$ Cornell University, Department of Animal Science, Ithaca, NY 14853-4801, USA
}

\section{Tiivistelmä}

Intensiivinen kotieläintalous ja sen aluellinen keskittyminen ovat keskeisiä tekijöitä maatalouden vesistökuormituksen kannalta. Empiiristen kenttäaineistojen mukaan maitotilojen fosforin (P) että typen $(\mathrm{N})$ porttitaseet ovat selvästi ylijäämäiset Suomessa. Intensiiviseen karjatalouteen, erityisesti maidontuotantoon, kohdistuukin tulevaisuudessa entistä suurempi paine vähentää ravinnepäästöjä, jotta sisä- ja murtovesien rehevöitymiskehitys voitaisiin katkaista.

Potentiaaliset peltoviljelyn ravinnehuuhtoumat ovat sidoksissa ravinnetaseeseen, vaikka lyhyellä aikavälillä (satovuosi) yhteys ei välttämättä ole kovin voimakas. Pidemmällä aikavälillä ravinnepäästöjä ei voida vähentää, ellei ravinneylijäämiä voida alentaa. Tämän tutkimuksen tavoitteena oli 1) mallintaa maitotilan P- ja N-kierto ja 2) testata mallin toimivuus riippumattomalla kenttäaineistolla. Tavoitteena oli, että mallin avulla voidaan kvantitatiivisesti estimoida maitotilan ravinnetase ja simuloida erilaisten peltoviljelyn ja maidontuotannon vaihtoehtojen vaikutuksia ravinnetaseisiin.

Maitotilamalli koostuu viidestä eri alamallista: karjan uudistus (1), maidontuotanto (2), karjanlanta (3), rehuviljely (4) sekä ravinnetaseet (5). Kasvinviljelyosiossa estimoidaan viljeltyjen kasvien sadot ja sadon sisältämä N- ja P-pitoisuus. Satofunktiot estimoitiin kotimaisten ruutusatokokeiden perusteella siten, että N- ja P-lannoituksen vaikutus kasvien satoon huomioitiin erillisinä. Plannoitusvasteen oletettiin riippuvan maan P-luvusta. Karjamallissa estimoidaan tietyn lehmämäärän tarvitsema nuorkarjan määrä, kun kaikki tilan eläimet kasvatetaan itse ja lehmien poiston osuus ja poikimisväli vaihtelevat. Simulointi rakennettiin Powersim -ohjelmalla. Ruokintamalli rakennettiin ympärivuotiselle säilörehuruokinnalle. Nuorkarjan tarvitsema rehumäärä laskettiin ruokintasuositusten mukaan, ja erotuksella saatiin lehmille jäävä rehusatomäärä. Lehmien tarvitsema rehumäärä laskettiin voimassa olevia ruokintasuosituksia noudattaen, mutta siten että normeja on mahdollista muuttaa eri simuloinneissa. Lehmien syöntipotentiaali mallinnettiin erikseen eläintekijöistä (tuotospotentiaali, elopaino) ja dieettitekijöistä (karkearehun laatu ja väkirehuruokinta) riippuvaksi. Lehmien dieetti optimoitiin pienimmän rehuannoksen hinnan perusteella keskimääräiselle tuotostasolle laktaation aikana ottaen huomioon lehmien syöntipotentiaali, tuotostaso sekä käytössä olevien rehujen laatu ja hinta. Maidontuotanto ja maidon koostumus laskettiin energian ja valkuaisen saannin mukaan perustuen todellisiin tuotosvasteisiin. Ravinnetaselaskennassa estimoidaan maitoon, eläimiin ja lantaan jakautuvat ravinteet, ja lasketaan tilan ravinteiden porttitaseet ottaen huomioon kasvien, maidon ja eläinten myynnit tilalta ulos ja ravinteiden ostot mm. lannoitteissa ja rehuissa. Mallin laskennat ja optimonnit tehtiin MS-excel taulukkolaskentaohjelmalla. Malli testattiin 26 maitotilan aineistolla, joilta oli käytettävissä 1-4 satovuoden tulokset ravinnetaseista.

Tulokset osoittivat, että mallilla estimoidut P- ja N-tilataseet korreloivat hyvin havaittujen tilataseiden kanssa $\left(P: R^{2}=0.800\right.$ ja N: $\left.R^{2}=0.876\right)$. Sekä mallilla simuloitujen että havaittujen tulosten perusteella tilalle ostettu fosforilannoitekilo lisäsi P-ylijäämää noin $1,2 \mathrm{~kg} / \mathrm{ha}$. Tämä johtuu todennäköisesti siitä, että tiloille ostettujen rehujen ja lannan fosforia ei huomioida riittävästi viljeltävien kasvien lannoituksessa. Johtopäätöksenä voidaan todeta, että maitotilan kasvinviljelyn ja maidontuotannon integroiva systeemimalli on hyvin käyttökelpoinen työkalu pyrittäessä löytämään tehostamiskeinoja ravinteiden hyväksikäytölle. Jatkotutkimuksissa mallia täydennetään laidunkierrolla ja nurmirehujen korjuustrategialla.

Asiasanat: maitotila, fosfori, ravinnekierto, mallinnus 


\section{Johdanto}

Vuosina 2000-2004 maatalouden osuus ihmistoiminnan aiheuttamasta vesistökuormituksesta Suomessa oli fosforikuorman osalta noin $60 \%$ ja typpikuorman osalta noin $50 \%$. Viimeisen vajaan 20 vuoden aikana maamme peltojen fosfori- ja typpitaseet ovat vähentyneet etenkin kasvintuotantoalueilla, kun taas intensiivisen kotieläintuotannon alueilla taseet ovat pysytelleet korkeampina (MMM 2004, Uusitalo ym. 2007, Salo ym. 2007). Tulevaisuudessa maatalouden aiheuttama vesistökuormitus on siten yhä suuremmalta osin sidoksissa ravinnepäästöihin intensiivisen kotieläintalouden alueilla. Erityisesti voimaperäisillä maidontuotantoalueilla, kuten Pohjanmaalla, peltojen fosforitaseet ovat muita alueita korkeampia (MMM 2004), ja näillä alueilla nautaeläinten tuottaman lannan ravinnesisältö on keskeinen kuormituksen taustatekijä (Yrjänen ym. 2003). Huolimatta monista toimenpiteistä mm. jo toteutetuissa ympäristötukijärjestelmissä, maataloudesta kuormituksensa saavien vesistöjen tila ei ole vielä merkittävästi parantunut (Räike ym. 2004). Mitattavien vaikutusten näkyminen vie aikaa, koska aikaisempien toimien vuoksi maaperään ja vesistöihin on varastoitunut runsaasti ravinteita. On myös mahdollista, että toimenpiteet ovat olleet riittämättömiä ja/tai väärin suunnattuja. Monet tukiohjelmien toimenpiteet, kuten peltojen suojakaistat tms., tavoittelevat ravinneylijäämien pidättämistä maahan eivätkä niinkään kvantitatiivista ravinnekierron hallintaa.

Empiiristen kenttäaineistojen mukaan maitotilojen fosforin $(\mathrm{P}, 11,7 \mathrm{~kg} / \mathrm{ha})$ että typen $(\mathrm{N}, 110$ $\mathrm{kg} / \mathrm{ha}$ ) porttitaseet ovat selvästi ylijäämäiset Suomessa (Virtanen \& Nousiainen 2005). Laskennallisen arvion mukaan 1900 -luvulla Suomen koko karjatalouden lantaan tuottama P-määrä nousi noin 7000 tonnista reiluun 20000 tonniin (Nousiainen J.I., julkaisematon). Vastaavasti kotieläintuotteisiin sitoutunut P-määrä kaksinkertaistui 2500 tonnista 5000 tonniin. Maidontuotannossa tuotantointensiteetin (kg maitoa/ha) lisäys yleensä johtaa ympäristön kannalta negatiiviseen kehitykseen (Virtanen \& Nousiainen, 2005). Tätä kehitystä on Suomen EU-jäsenyyden ajan vauhdittanut suhteellisen korkea maidon hinta suhteessa viljan ja valkuaisrehujen hintaan. Tämä on johtanut siihen, että ruokintaintensiteettiä on kannattanut nostaa, mutta aleneva lisätuotos (kg maitoa/lisäväkirehukilo) on johtanut jyrkästi lisääntyneeseen lannan P-kuormitukseen maitokiloa kohden (Yrjänen ym. 2003). Samaan aikaan maitotilojen rakennekehitys on ollut suurelta osin tilan ulkopuolelta ostettujen rehujen varassa lisäten tilojen P-ylijäämää. Ylimääräinen lannan P olisi tietenkin hyödynnettävissä kasvinviljelyssä, mutta kasvinviljelytilojen vähäinen määrä intensiivisen maidontuotannon alueilla rajoittaa tätä. Rakennemuutos ja ruokintaintensiteetin kasvu onkin johtanut siihen, että maitotilojen keskimääräinen P-ylijäämä on nousussa, vaikka kokonaistuotanto on laskenut. Maatalouden ympäristötutkimus on pitkälti keskittynyt ravinnekierron (maaperä, kasvinviljely, ruokinta, lanta, huuhtoumat) yksityiskohtien tutkimukseen. Tämän sinänsä arvokkaan ja välttämättömän tiedon hyödyntäminen voi kuitenkin jäädä tehottomaksi ilman koko ravinnekierron kokonaisvaltaista ja kvantitatiivista hallintaa. On mahdollista että esimerkiksi ruokinnan ravintoaineiden hyväksikäyttöä parannetaan, mutta tilasysteemitason hyväksikäyttö voi samalla huonontua jos ruokinnan muutos tehdään ostopanoksilla.

Intensiiviseen karjatalouteen, erityisesti maidontuotantoon, kohdistuukin tulevaisuudessa entistä suurempi paine vähentää ravinnepäästöjä, jotta vesistöjen rehevöitymiskehitys voitaisiin katkaista. Potentiaaliset peltoviljelyn ravinnehuuhtoumat ovat sidoksissa ravinnetaseeseen, vaikka lyhyellä aikavälillä (satovuosi) yhteys ei välttämättä ole kovin selkeä (Ekholm ym. 2005). Maan P-luvun noustessa matalalta tasolta satotaso nousee ensin nopeasti, mutta potentiaalinen huuhtoumariski kasvaa jyrkästi kun P-luku kasvaa keskimääräistä suuremmaksi (Sharpley ym. 2003). Pidemmällä aikavälillä ravinnepäästöjä ei voida vähentää, ilman että kvantitatiivinen ravinnetase alenee. Tämän tutkimuksen tärkeimpänä tavoitteena oli kehittää maitotilan systeemimalli ravinteiden hyväksikäytön ja ravinneylijäämien laskemiseksi. Lisäksi tavoitteena oli testata mallin toimivuus riippumattomalla kenttäaineistolla ja arvioida yksittäisten rehuviljely $\mathrm{n}$ ja ruokinnan toimenpiteiden vaikutuksia ravinteiden hyväksikäyttöön ja ravinneylijäämiin ( $\mathrm{N}$ ja $\mathrm{P})$.

\section{Aineisto ja menetelmät}

Malli koostuu viidestä eri alamallista: karjan uudistus (1), maidontuotanto (2), karjanlanta (3), rehuviljely (4) sekä ravinnetaseet (5) (Kuvio 1). Malli on rakennettu pääosin Excel® taulukkolaskentaohjelmalla.

\section{Karjan uudistus}


Mallissa lasketaan lehmien uudistukseen tarvittava nuorkarjan määrä uudistusnopeuden ja poikimavälin mukaan (Huhtanen \& Nousiainen 2006). Lehmien poistotarve eri tuotannon vaiheissa sekä vasikoiden kuolleisuus laskettiin karjantarkkailuaineiston perusteella (Nousiainen ym. 2006). Malli olettaa että syntyneet sonnivasikat (0.52) ja ylimääräiset lehmävasikat myydään heti syntymän jälkeen. Vakiolehmämäärä ylläpidetään lehmävasikoiden myynnillä. Mallintaminen tehtiin Powersim ${ }^{\circledR}-$ ohjelmistolla, joka voi kommunikoida Excel ${ }^{\circledR}$ taulukkolaskentaohjelmalla kanssa.

Nuorkarjan ja umpilehmien ravinnontarpeet (kasvu, tiineys) laskettiin suomalaisten ruokintasuositusten mukaan (MTT, 2006). Laskennallinen fosforin saanti perusrehuista (säilörehu, vilja ja rypsi) oli riittävä kaikille eläinryhmille ilman kivennäisfosforia.

\section{Maidontuotanto}

Lehmien ruokinnat laskettiin lypsykauden keskimääräisen tuotoksen ja maidon koostumuksen mukaan. Yksinkertaistettu malli on perusteltu, koska lypsykauden jakaminen kolmeen osaan johti keskimäärin samanlaiseen dieettiin, jota myös tutkimustulokset tukevat.

Päivittäinen lehmien ravinnontarve (ME, OIV $, \mathrm{Ca}, \mathrm{P}, \mathrm{Na}$ ja $\mathrm{Mg}$ ) laskettiin suomalaisten suositusten perusteella (MTT 2006). Karkearehujen energia- (MJ ME/kg KA) ja valkuaisarvo (OIV, g/kg KA) laskettiin D-arvon ja raakavalkuaispitoisuuden mukaan (MTT 2006). Ostoväkirehujen ME- ja OIV-arvot laskettiin taulukoiden koostumuksen ja sulavuuksien mukaan (MTT 2006). Kotoisten rehujen kivennäispitoisuus laskettiin N- ja P-lannoituksen perusteella. Lehmien ME-tarve laskettiin seuraavasti:

$$
\mathrm{ME} \text { tarve }(\mathrm{MJ} / \mathrm{pv})=0.515 \times \mathrm{EP}^{0.75}+5.15 \times \mathrm{EKM}
$$

missä EP = elopaino $(\mathrm{kg})$ ja EKM = energiakorjattu maitotuotos $(\mathrm{kg} / \mathrm{pv})$. Todellinen ME-saanti laskettiin korjaamalla taulukkoarvojen perusteella laskettu energiansaanti väki- ja karkearehujen negatiivisten yhdysvaikutusten ja korkeamman ruokintatason mukaan seuraavasti:

$$
\mathrm{ME}_{\text {tod }}(\mathrm{MJ} / \mathrm{pv})=13.6+0.936 \times \mathrm{MEI}-29.5 \times \mathrm{VR}_{\text {osuus }}
$$

missä MEI $=\mathrm{ME}$ saanti (taulukkoarvot) $\mathrm{ja} \mathrm{VR}_{\text {osuus }}=$ väkirehun osuus dieetin kuiva-aineessa (0-1).

Lehmien fosforin (P)tarve laskettiin seuraavasti

$$
\mathrm{P}(\mathrm{g} / \mathrm{pv})=\left(0.002 \times \mathrm{EP}+1.0 \times \mathrm{KA}_{\text {syo }}+0.9 \times \text { Maito }\right) / 0.70
$$

missä $\mathrm{KA}_{\text {syo }}=$ kuiva-aineen syönti $(\mathrm{kg} \mathrm{KA} / \mathrm{pv})$ ja maidon P pitoisuus $0,9 \mathrm{~g} / \mathrm{kg}$ ja rehujen P:n hyväksikäyttö oletettiin vakioiksi (0.70).

Lehmille käytettävissä olevien kotoisten rehujen määrä laskettiin vähentämällä rehusadosta nuorkarjan ja umpilehmien tarvitsema rehumäärä. Tilalla tuotettujen rehujen ylimäärä myytiin tilalta ulos. Lehmien kuiva-aineen syöntipotentiaali $\left(\mathrm{KASYO}_{\max }\right)$ laskettiin seuraavasti:

$$
\mathrm{KASYO}_{\max }(\mathrm{kg} \mathrm{KA} / \mathrm{pv})=\mathrm{a}+\mathrm{b} \times \mathrm{EP}+\mathrm{c} \times \mathrm{EKM}+0.1 \times(\mathrm{TDMI} \text { indeksi }-100)
$$

missä a, b and c ovat vakioita ja TDMI indeksi kuvaa koko dieetin syöntipotentiaalia ja se laskettiin Rinne ym. (2008) kuvaamalla tavalla.

Lehmien päivittäisen rehuannoksen optimointi tehtiin Excel@ taulukkolaskentaohjelman Solver -työkalulla. Optimoinnissa huomioitiin syöntikyky, ruokintasuositukset, pötsifysiologiset rajoitukset (karkearehujen NDF:n saanti sekä tärkkelyksen ja rasvan pitoisuudet) sekä rehujen hinnat. Karkearehujen hinta koostui kaikista (kiinteät ja muuttuvat) kustannuksista minimikarkearehun tarpeelle (kg ka/pv) ja tätä ylittävältä osalta muuttuvista kustannuksista. Ostoväkirehuille käytettiin markkinahintoja.

Lehmien maidontuotanto optimoiduilla dieeteillä laskettiin empiirisellä regressioyhtälöllä, joka on estimoitu lehmien tuotosvasteaineistosta mixed regressiolla kokeiden välisen vaihtelun poistamiseksi (kts. Huhtanen ym. 2008). Tuotosvasteaineisto rajattiin siten, että kokeen keskimääräinen tuotos oli vähintään $25 \mathrm{~kg} / \mathrm{pv}$, jolloin aineistoon jäi 495 dieettikohtaista havaintoa. Tuotosvasteet ( $\mathrm{Y}_{\text {mai- }}$ to, $\left.\mathrm{Y}_{\mathrm{EKM}}, \mathrm{Y}_{\text {valkuainen }}\right)$ laskettiin seuraavasti:

$$
\begin{aligned}
& \mathrm{Y}=\mathrm{a}+\mathrm{b} \times \mathrm{ME}_{\text {tod }}+\mathrm{c} \times \mathrm{ME}_{\text {tod }}{ }^{2}+\mathrm{d} \times \mathrm{ROV}+\mathrm{e} \times \mathrm{ROV}^{2}+\mathrm{f} \times \mathrm{TÄRK}+\mathrm{g} \times \mathrm{T}^{\mathrm{ARK}}{ }^{2} \\
& +\mathrm{h} \times \mathrm{VR}_{\text {ras }}+\mathrm{i} \times \mathrm{VR}_{\text {ras }}{ }^{2}
\end{aligned}
$$

missä, $\mathrm{ME}_{\text {tod }}=$ korjattu ME-saanti $(\mathrm{MJ} / \mathrm{pv}, \mathrm{ROV}=$ ohitusvalkuaisen saanti $(\mathrm{kg} / \mathrm{pv})$ sekä TÄRK ja $\mathrm{VR}_{\text {ras }}$ rehuannoksen tärkkelys- ja raakarasvapitoisuus $(\mathrm{g} / \mathrm{kg} \mathrm{KA})$.

\section{Karjanlanta}

Lypsävien lehmien lannan typpi jaettiin sonnan ja virtsan typpeen seuraavasti:

$$
\text { Virtsan } \mathrm{N}(\mathrm{g} / \mathrm{pv})=16.9( \pm 11.0)-12.3( \pm 0.69) \times \mathrm{KA}_{\text {Syo }}+0.108( \pm 0.011) \times \mathrm{N}_{\mathrm{sa}}
$$


Sonnan $\mathrm{N}(\mathrm{g} / \mathrm{pv})=-17.7( \pm 9.7)+6.3( \pm 0.62) \times \mathrm{KA}_{\text {Syo }}+0.833( \pm 0.012) \times \mathrm{N}_{\mathrm{sa}}$ missä $\mathrm{N}_{\mathrm{sa}}=$ typen $(\mathrm{N})$ saanti (g/pv). Nuoren karjan ja umpilehmien lannan typpi jaettiin virtsan ja sonnan typpeen ns. Lucasin yhtälöllä. Sonnan typen osuus laskettiin: sonnan RV/koko dieetin RV. Eläimiin sitoutunut typen osuus laskettiin jakamalla tilalta poistettuihin eläimiin sitoutunut typpi nuoren karjan ja umpilehmien ruokintaan käytetyllä typpimäärällä. Nuorenkarjan virtsan typpi laskettiin seuraavasti:

Virtsan $\mathrm{N}$ osuus $=(\mathrm{N}$ syönti - Sonnan $\mathrm{N}-$ Eläimiin sitoutunut $\mathrm{N}) / \mathrm{N}$ syönti

Malli olettaa että lanta käsitellään lietelantana; ja kokonais- $\mathrm{N}$ ja $\mathrm{P}$ lietteessä lasketaan:

$$
\begin{aligned}
& \mathrm{N}_{\text {liete }}=\mathrm{N}_{\text {rehut }}-\mathrm{N}_{\text {maito }}-\mathrm{N}_{\text {eläimet }}-0.10 \mathrm{x} \text { Virtsan } \mathrm{N} \\
& \mathrm{P}_{\text {liete }}=\mathrm{P}_{\text {rehut }}-\mathrm{P}_{\text {maito }}-\mathrm{P}_{\text {eläimet }}
\end{aligned}
$$

missä rehujen ravinteet on laskettu kaikkien eläinryhmien ruokinnasta (tilalla tuotetut rehut ja ostorehut). Virtsan ammoniakin haihdunta oletettiin olevan $10 \%$. Tilalta myydyn maidon $\mathrm{N}$ ja $\mathrm{P}$ laskettiin seuraavasti:

$$
\begin{aligned}
& \mathrm{N}_{\text {maito }}(\mathrm{kg})=0.95 \times \text { Maitotuotos } \times 0.157 \times \mathrm{RV}_{\text {maito }} \\
& \mathrm{P}_{\text {maito }}(\mathrm{kg})=0.95 \times \mathrm{P}_{\text {maito }} \times \text { Maitotuotos }
\end{aligned}
$$

missä maidon P pitoisuus oletetaan vakioksi $(0.9 \mathrm{~g} / \mathrm{kg})$. Maidon myyntiosuus on oletusarvona 0.95 kokonaistuotoksesta. Tilalta myytyihin eläimiin sitoutuneet ravinteet laskettiin ARC (1980) taulukkoarvojen mukaan seuraavasti:

$$
\begin{aligned}
& \mathrm{N}_{\text {eläimet }}(\mathrm{kg})=0.0214 \times \mathrm{EP}(\mathrm{kg})+0.299 \\
& \mathrm{P}_{\text {eläimet }}(\mathrm{kg})=0.0067 \times \mathrm{EP}(\mathrm{kg})+0.055
\end{aligned}
$$

\section{Rehuviljely}

Tilan viljelykierto kuvataan mallissa seuraavasti:

$$
\begin{aligned}
& \text { A (ha) }=\mathrm{a}_{1} \times \mathrm{K}+\mathrm{a}_{2} \times \mathrm{K}+\mathrm{a}_{3} \times \mathrm{KV}+\mathrm{a}_{4} \times \mathrm{NU} 1+\mathrm{a}_{5} \times \mathrm{NU} 2+\mathrm{a}_{6} \times \mathrm{NU} 3+\mathrm{a}_{7} \times \mathrm{NU} 4 \\
& +\mathrm{a}_{8} \times \mathrm{KE}
\end{aligned}
$$

missä $\mathrm{A}=$ kokonaisala, $\mathrm{K}=$ kaura, $\mathrm{O}=$ ohra, $\mathrm{KV}=$ kokoviljasäilörehu, $\mathrm{NU}=$ nurmi ja $\mathrm{KE}=$ kesanto. Nurmen ikä voi olla 1-4 vuotta $\left(\mathrm{NU}_{1}-\mathrm{NU}_{4}\right)$. Parametrit $\mathrm{a}_{1}-\mathrm{a}_{8}$ määrittävät kunkin kasvin osuuden kokonaisalasta. Peltoala $(A)$ voidaan jakaa vielä kivennäismaihin $\left(\mathrm{s}_{1}\right)$ tai eloperäisiin maihin $\left(\mathrm{s}_{2}\right)$ :

$$
A(h a)=s_{1} \times A+s_{2} \times A
$$

Oletuksena on että kaikkia viljelykierron kasveja viljellään annetussa maalajien suhteessa $\left(\mathrm{s}_{1}\right.$ ja $\left.\mathrm{s}_{2}\right)$ tasan. Peltojen kasvukuntoa määritetään parametrilla $\mathrm{p}_{1}$. Kasvukuntoon vaikuttavat mm. maan $\mathrm{pH}$, vesitalous ja maan ravinteikkuus ja rakenne. Oletusarvo 1 kuvaa keskimääräistä kasvukuntoa. Keskisatotaso $(\mathrm{S})$ lasketaan seuraavasti:

$\mathrm{S}(\mathrm{kg} \mathrm{KA} / \mathrm{ha})=\mathrm{p}_{1} \times \mathrm{p}_{2} \times \mathrm{S}_{\mathrm{e}}(\mathrm{kg} \mathrm{KA} / \mathrm{ha})$

missä parametrilla $\mathrm{p}_{2}$ muunnetaan koeruutusato $\left(\mathrm{S}_{\mathrm{e}}\right)$ talouspeltojen sadoksi ja sen oletusarvo on 0.8 .

Maan P-luku (SPT) lasketaan seuraavasti:

$$
\mathrm{SPT}(\mathrm{mg} / \mathrm{l})=\mathrm{STP}_{0}+\left(0.0867+0.000906 \times \mathrm{SPT}_{0} \times \mathrm{P}_{\mathrm{t}}-0.01869 \times \mathrm{SPT}_{0}\right)
$$

missä $\mathrm{SPT}_{0}(\mathrm{mg} \mathrm{g} / \mathrm{l})$ kuvaa maan P lukua ajanhetkellä 0 ja $\mathrm{P}_{\mathrm{t}}$ on $\mathrm{P}$ porttitase $(\mathrm{kg} / \mathrm{ha})$. Yhtälö [18] on muodostettu kotimaisten P-lannoituskokeiden tuloksista (Saarela 1995) soveltaen Ekholm ym. (2005) laskentamenetelmiä. Viljelykasvien lannoitus mallinettiin seuraavasti:

$$
\begin{aligned}
& \mathrm{N}(\mathrm{kg} / \mathrm{ha})=\mathrm{N}_{\mathrm{s}}(\mathrm{kg} \text { ha- } 1) \times\left(1-\mathrm{s}_{\mathrm{N}} \times \mathrm{v}_{\mathrm{N}}\right)+\mathrm{N}_{\mathrm{m}}(\mathrm{kg} \text { ha- } 1) \\
& \mathrm{P}(\mathrm{kg} / \mathrm{ha})=\mathrm{P}_{\mathrm{s}}(\mathrm{kg} \text { ha- } 1)+\mathrm{P}_{\mathrm{m}}(\mathrm{kg} \text { ha- } 1)
\end{aligned}
$$

missä $N_{s}$ ja $P_{s}$ kuvaavat lietelannan sekä $N_{m}$ ja $P_{m}$ väkilannoitteiden ravinteita. Parametrit $s_{N} j a v_{N} k u-$ vaavat lietelannan liukoisen typen määrää ja haihtumistappiota levityksen yhteydessä. Parametrin $\mathrm{s}_{\mathrm{N}}$ oletusarvo on 0,5 ja $_{\mathrm{N}} 0,15$ (kevätlevitys ja multaus), 0,45 (hajalevitys nurmen pintaan) tai 0,33 (letkulevitys nurmelle). Lannan fosforin hyväksikäytön oletusarvo on 0,85 . Oletuksena malli jakaa lietelannan eri kasveille seuraavasti: muokattavalle peltoalalle nitraattidirektiivin mukainen maksimimäärä ja loput nurmelle. Lannoituksen satovasteet saadaan N-lannoituksen (2. asteen polynomi) ja P-vasteen summana seuraavasti:

$$
\mathrm{KA}_{\text {sato }}(\mathrm{kg} / \mathrm{ha})=\mathrm{a}+\mathrm{b} \times \mathrm{N}(\mathrm{kg} / \mathrm{ha})+\mathrm{c} \times \mathrm{N}^{2}(\mathrm{~kg} / \mathrm{ha})+\mathrm{P}_{\text {res }}(\mathrm{kg} / \mathrm{ha})
$$

missä $N$ on typpilannoituksen kokonaismäärä [19] ja a, b ja c ovat vakioita. Fosforin aiheuttama lisäsato $\left(\mathrm{P}_{\text {res }}\right)$ on maan P-luvun ja P-lannoituksen [20] funktio suhteutettuna perustasoihin (P luku $10 \mathrm{mg} / \mathrm{l}$ ja P-lannoitus $15 \mathrm{~kg} / \mathrm{ha}$ ). Lannoituksen ( $\mathrm{N} \mathrm{ja} \mathrm{P}$ ) vaikutukset kasvien $\mathrm{RV}$ - ja P-pitoisuuksiin laskettiin erikseen regressioyhtälöillä jotka estimoitiin kotimaisista lannoituskokeista (Saarela 1995). 


\section{Ravinnetaseet}

Ravinteiden porttitaseet typelle $\left(\mathrm{N}_{\mathrm{t}}, \mathrm{kg} / \mathrm{ha} /\right.$ vuosi) ja fosforille $\left(\mathrm{P}_{\mathrm{t}}, \mathrm{kg} / \mathrm{ha} / \mathrm{vuosi}\right)$ laskettiin seuraavasti:

$$
\begin{aligned}
& \mathrm{N}_{\mathrm{t}}=\left(\mathrm{N}_{\mathrm{o}}-\mathrm{N}_{\mathrm{my}}\right) / \mathrm{A} \\
& \mathrm{P}_{\mathrm{t}}=\left(\mathrm{P}_{\mathrm{o}}-\mathrm{P}_{\mathrm{my}}\right) / \mathrm{A}
\end{aligned}
$$

missä $\mathrm{N}_{\mathrm{o}}$ ja $\mathrm{P}_{\mathrm{o}}$ ovat ravinteiden ostot tilalle (väkilannoitteet, rehut, lanta, siemenet ja eläimet) ja $\mathrm{N}_{\mathrm{my}} \mathrm{ja}$ $\mathrm{P}_{\mathrm{my}}$ ravinteiden myynnit tilalta (kasvit, maito, lanta ja eläimet). Taseessa ei huomioitu ravinteiden poistumista kierrosta haihtumalla tai huuhtoutumalla, eikä ilmalaskeumaa otettu huomioon.

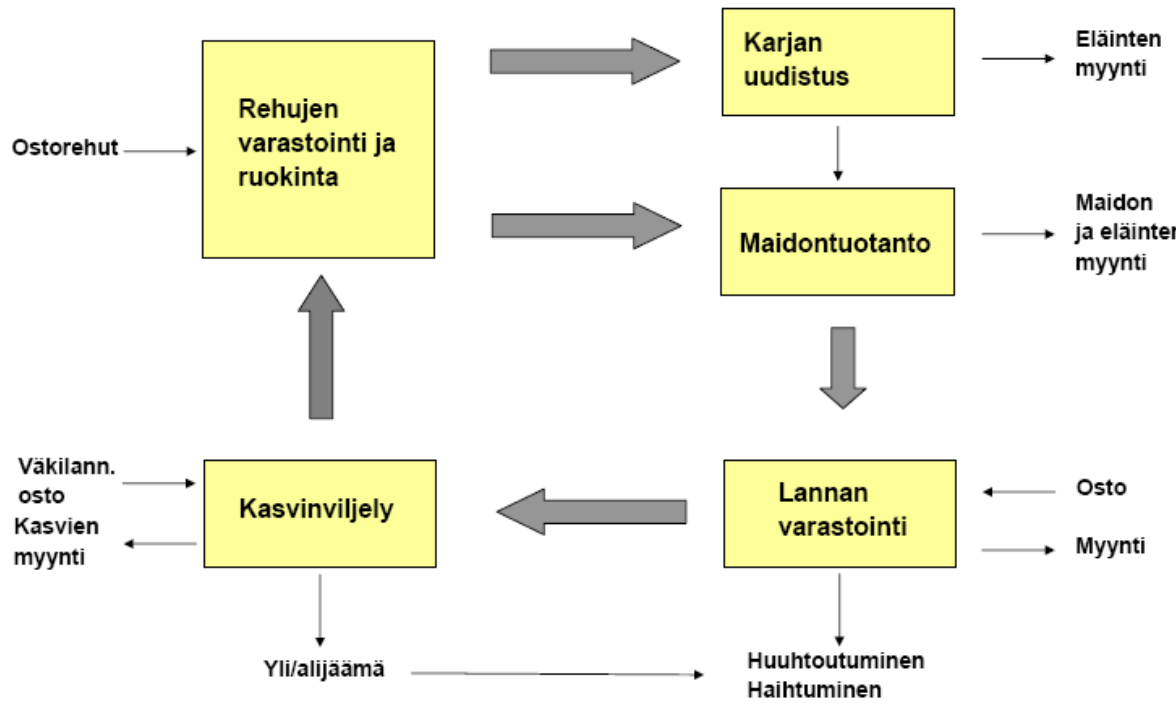

Kuvio 1. Maitotilan ravinnekiertomallin kaavamainen esitys

\section{Tulokset ja niiden tarkastelu}

\section{Mallin testaus kenttäaineistolla}

Testausta varten kerättiin Keski-Pohjanmaalta 26 maitotilan kenttäaineisto, jonka taustatiedot on esitetty Taulukossa 1. Tiloille laskettiin 1-4 vuoden tiedoista $N$ ja P keskimääräiset porttitaseet $(\mathrm{kg} / \mathrm{ka}) \mathrm{ja}$ simuloitiin maitotilamallilla vastaavasti. Simulointi tehtiin tilojen ilmoittamalla väkilannoitekäytöllä ja viljelykierrolla käyttäen satokertoimena 0.8 (lannoituksen satovaste $=0.8 \times 0.8=0.64$ ruutukoesato). Jos tiloilla oli lihanautoja, otettiin se simuloinnissa huomioon. Lehmien ruokinta optimointiin pienimmän rehukustannuksen mukaan käyttäen tilan havaitusta keskituotoksesta laskettua laktaatiokauden (305 pv) päiväkeskituotosta. Väkirehuina optimoinnissa käytettiin tilan omaa viljaa, ostoviljaa, melassileikettä, rypsipuristetta ja -rouhetta sekä kivennäisrehuja. Simuloinnissa käytetyt rehujen ja maidon hinnat olivat vuoden 2006 keskihintoja. Maan P-luvun oletettiin olevan 15 mg/l.

Ravinnekiertomallin testaus kenttäaineistolla osoitti havaittujen ja simuloitujen ravinnetaseiden vastaavan varsin hyvin toisiaan (Kuvio $2 ; \mathrm{R}^{2}=0.800 \mathrm{ja} \mathrm{R}^{2}=0.876 \mathrm{P}$ - ja $\mathrm{N}$-taseelle). Mallin virhe (keskipoikkeama y $=$ x suoralta) oli 2.5 ja $12.5 \mathrm{~kg} / \mathrm{ha} \mathrm{P}$ - ja N-taseelle. Kun keskimääräisessä tasossa simuloitujen ja havaittujen taseiden välillä ei ollut merkittävää eroa, johtui virhe suureksi osaksi kulmakerroin- ja satunnaisvirheestä. Testiaineiston maitotilojen havaitut ja simuloidut ravinneylijäämät vastasivat hyvin Virtasen ja Nousiaisen (2005) suuremmasta tila-aineistosta laskemia ylijäämiä.

Tila-aineistosta (Taulukko 1) simuloitujen tulosten vastaavuus havaittuihin ravinnetaseisiin johtuu ainakin osittain siitä, että mallin ruokintavasteet perustuvat todellisen ravinnonsaannin lisäyksen maitotuotosvasteisiin lypsylehmillä (Huhtanen ym. 2008). Aiemmin julkaistut mallit (mm. Buysse ym. 2005) perustuvat yleensä ruokinnan osalta taulukkoarvoihin, joiden käyttö johtaa vääjäämättä ruokintavasteiden yliarviointiin, ja ravinnetaseiden aliarviointiin (Huhtanen ym. 2008). Osa mallin virheestä voi tulla siitä, että peltojen kasvukunto oletettiin kaikilla tiloilla samaksi (kasvukerroin 0.8), vaikka tilojen väliset erot pellon tuottavuudessa rajatullakin alueella ovat hyvin todennäköisiä. On mahdollis- 
Taulukko 1. Ravinnekiertomallin testaukseen käytetyn tila-aineiston taustatiedot ja laskennalliset ravinnetaseet $(\mathrm{n}=26)$

\begin{tabular}{lrrrr}
\hline & Keskiarvo & Min & Maks & Keskihajonta \\
\hline Pelto, ha & 43.2 & 10.6 & 87.8 & 19.61 \\
Väkilannoite N, kg/ha & 97.3 & 51.8 & 144.0 & 24.86 \\
Ostorehujen N, kg/ha & 33.1 & 1.4 & 82.8 & 18.94 \\
Väkilannoite P, kg/ha & 11.0 & 6.4 & 20.7 & 3.30 \\
Ostorehujen P, kg/ha & 7.5 & 1.3 & 16.6 & 3.58 \\
Lehmiä, kpl & 20.4 & 4.6 & 47.5 & 8.82 \\
Lehmiä, kpl/ha & 0.51 & 0.2 & 1.00 & 0.168 \\
Lehmien poisto, \% & 32.6 & 4.5 & 76.8 & 17.61 \\
Keskituotos, kg/vuosi & 8007 & 4059 & 10131 & 1146.4 \\
Maitotuotos, kg/ha & 3970 & 868 & 7536 & 1492.9 \\
Havaittu N-tase, kg/ha & 104.1 & 53.3 & 163.9 & 30.80 \\
Havaittu P-tase, kg/ha & 13.7 & 6.5 & 25.3 & 4.46 \\
\hline
\end{tabular}
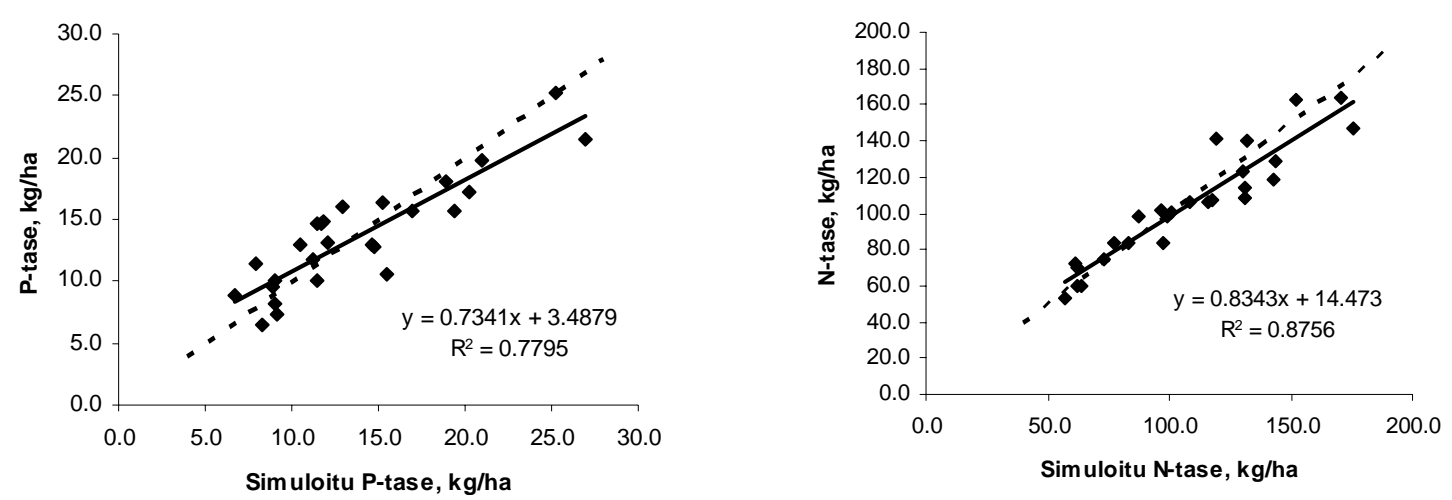

Kuvio 2. Ravinnekiertomallin testaus kenttäaineistolla; simuloitujen ja havaittujen ravinnetaseiden yhteys Keski-Pohjanmaan maitotiloilla $(\mathrm{n}=26$, katkoviiva $\mathrm{y}=\mathrm{x})$

ta että käytetty kasvukerroin (0.8) on keskimäärin hieman liian suuri. Simulointien mukaan tiloille jäi keskimäärin rehukasvien ylijäämää, joka vastasi 7.1 ja $1.0 \mathrm{~kg} / \mathrm{ha} \mathrm{N}$ ja $\mathrm{P}$, eikä tätä otettu huomioon simuloiduissa taseissa. Toinen mahdollisuus on, että rehujen varastointitappiot arvioitiin mallissa liian pieniksi (säilörehulle 0.15). Lisäksi niillä tiloilla joilla on lehmämäärään nähden runsaasti peltoa, voi peltoviljely olla ekstensiivisempää, eikä peltojen kasvukunnon ylläpitoon ja parantamiseen panosteta. Mallissa ei ole laidunkautta mukana, vaan se olettaa ympärivuotisen säilörehuruokinnan. Tämäkin todennäköisesti voi selittää eroa simuloidun ja havaitun ravinnetaseen välillä.

\section{Eräitä simulointien tuloksia}

Uusimpien tutkimusten mukaan lypsylehmät eivät tarvitse lisäkivennäisfosforia ruokinnassa säilörehuruokinnalla kun väkirehuna on vilja ja rypsirouhe (Yrjänen ym. 2003). Viljan ja rypsirouheen P riittää jopa ylittämään lehmän P-tarpeen (keskituotos $9000 \mathrm{~kg} /$ vuosi). Simulointitulosten mukaan lehmien kivennäisrehun P-pitoisuuden noustessa tilalle ostettu fosforikilo lisää tilan porttitasetta $1 \mathrm{~kg} / \mathrm{kg}(\mathrm{Ku}-$ vio 3), kun eläintiheys on 0.7 lehmää hehtaarille ja maitoa tuotetaan $6300 \mathrm{~kg} / \mathrm{ha}$. Tämä ylimääräinen kivennäinen lisää tilan kustannuksia ja lannanlevitysalan tarvetta jopa $10 \%$.

Wattiaux'n (2001) esittämän mallin mukaan ylijäämäisen P-porttitaseen tulisi vähentää väkilannoitefosforin ostoa maitotilalle kun ravinnekiertoa säädellään järkiperäisesti. Testiaineistosta (Taulukko 1) lasketun regressioanalyysin mukaan sekä simuloidun että havaitun P-tilataseen yhteys tilalle ostettuun väkilantafosforiin oli hyvin vahva. Tilalle ostettu kilo lannoitefosforia lisäsi sekä simuloitua että havaittua $\mathrm{P}$-tasetta (regression kulmakertoimet $+1,22 \mathrm{ja}+1,19 \mathrm{~kg} /$ ha per kilo lannoite $\mathrm{P}, \mathrm{P}<0.001$ ). 
Virtasen ja Nousiaisen (2005) raportoima kulmakerroin oli $1,1 \mathrm{~kg} / \mathrm{ha}$ ja heidän herkkyysanalyysinsa mukaan tilatasetta voidaan muuttaa helpoimmin väkilannoite P:n määrällä kuten Wattiaux'n (2001) malli olettaa. Samaan lopputulokseen ovat päätyneet myös van Bruchem ym. (1999). Ostetun Plannoitemäärän ja P-taseen välisen regressioyhtälön leikkauspiste oli noin $0.5 \mathrm{~kg} / \mathrm{ha}$, mikä osoittaa että maitotilalla voitaisiin teoriassa pärjätä nykyistä huomattavasti pienemmällä väkilannoitefosforimäärällä, elleivät peltomaat ole fosforia voimakkaasti pidättäviä ja karjanlannan tehokas käyttö on teknisesti mahdollista. Testaukseen käytetyssä tila-aineistossa lannoite- ja ostorehun fosforin $(\mathrm{kg} / \mathrm{ha})$ välillä ei ollut merkitsevää yhteyttä, ja regressio oli jopa lievästi positiivinen. Tämä tuli myös esille suuremmassa tila-aineistossa aiemmin (Virtanen \& Nousiainen 2005). Tämä osoittaa että ravinteiden hyväksikäyttö ei ole maitotiloilla kovin suunnitelmallista, koska rehujen mukana tilalle ostetun fosforin määrää ei huomioida.

Simuloinnin mukaan (Kuvio 4) lisättäessä väkilantafosforin käyttöä 0-15 kg/ha, lisäsi ostolannoitefosforin käyttö tilatasetta $0,98 \mathrm{~kg} / \mathrm{ha} / \mathrm{kg}$. Tulos osoittaa että maitotilalla olisi helppo säädellä fosforin hyväksikäyttöä laskemalla vuosittainen porttitase ja muuttamalla sen mukaan lannoitefosforin käyttömäärää. Tätä menettelyä on ehdotettu myös ulkomaisten tutkimusten johtopäätöksissä (mm. Van Bruchem ym. 1999).

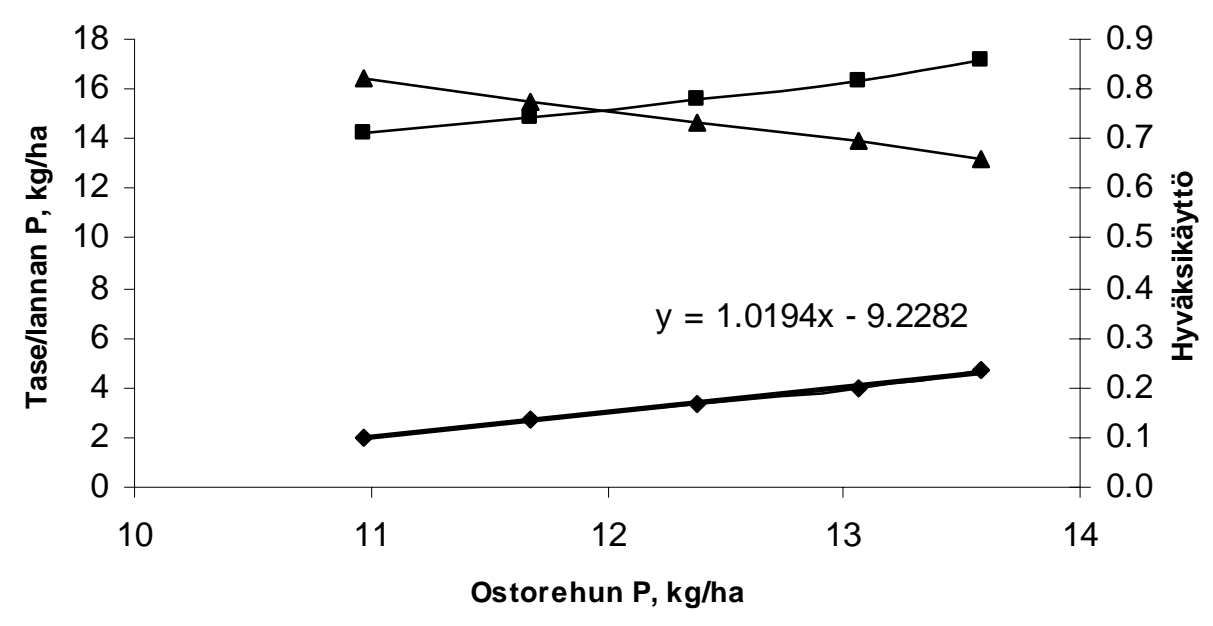

Kuvio 3. Simulointi kivennäisrehun P-pitoisuuden $(0,10,20,30$ tai $40 \mathrm{~g} / \mathrm{kg})$ vaikutuksesta tilan Ptaseeseen (४), lannan P-määrään (•) ja hyväksikäyttöön ( $\mathbf{\Delta}$ ) kun karjan tuotostaso on $9000 \mathrm{~kg} / \mathrm{vuosi}$, rehuina käytetään säilörehua, viljaa, rypsiä ja kivennäisrehua sekä ruokinnat optimoidaan maksimaalisen maitotuotto-rehukustannus erotuksen mukaan. Tilalla 0.7 lehmää/ha ja väkilannoitefosforia ei käytetä.

Lannoitekäytön pysyessä vakiona on tilan peltojen kasvukunto (satotaso) merkittävä tekijä koko tilan ravinteiden hyväksikäytön kannalta. Ravinnekiertomallissa tätä kuvaa kasvukuntokerroin, joka on 1.0 kun tilalla saadaan keskimääräinen sato (satotaso noin $4500 \mathrm{ry} / \mathrm{ha}$ ). Kun peltojen tuotto lisääntyy, ostorehutarve vähenee tai rehuja voidaan myydä ja tuloksena ravinnetase paranee. Simuloinnin mukaan (Kuvio 5) satotason lisääntyessä $1000 \mathrm{ry} / \mathrm{ha}$, vähenee fosforin ylijäämä 3,6 kg/ha mikäli satotason parantamiseen ei tarvita lannoitefosforin lisäämistä. Myös Van Bruchem ym. (1999) mallinnuksen mukaan rehukasvien ravinteiden hyväksikäytön tehostaminen on toiseksi tehokkain tapa vaikuttaa tilan fosforitaseeseen. 


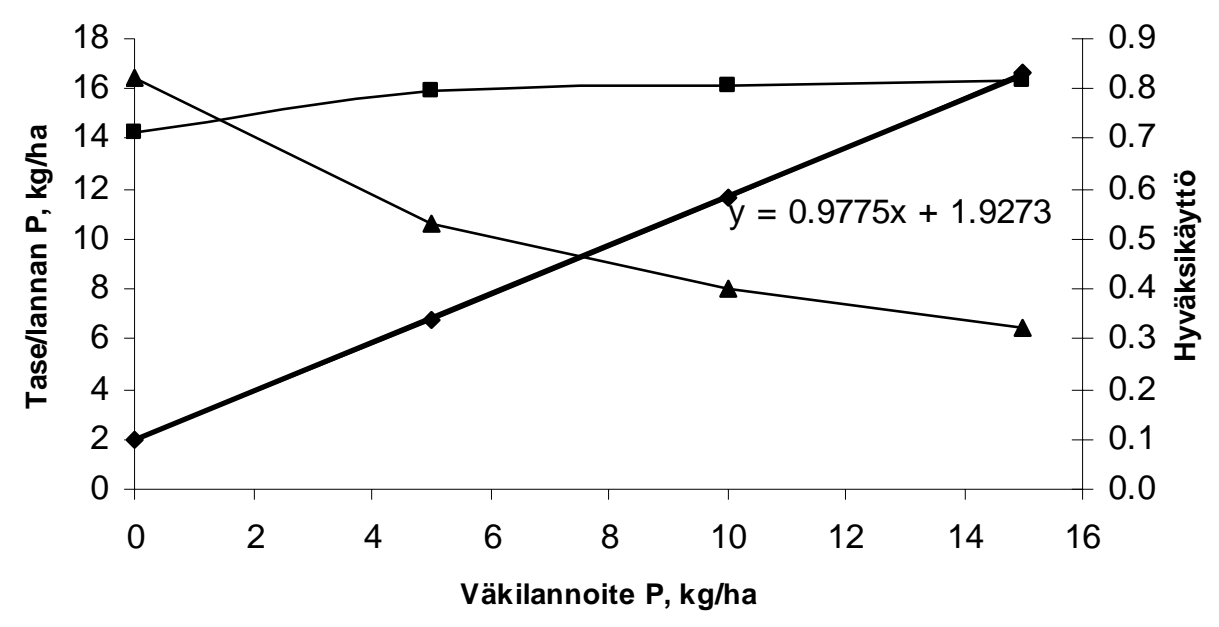

Kuvio 4. Simulointi väkilannoite P:n (keskimäärin $0,5,10,15 \mathrm{~kg} / \mathrm{ha}$ ) vaikutuksesta tilan P-taseeseen

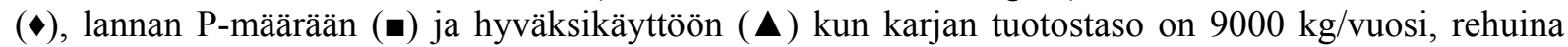
käytetään säilörehua, viljaa, rypsiä ja kivennäisrehua (ei fosforia) sekä ruokinnat optimoidaan maksimaalisen maitotuotto-rehukustannus erotuksen mukaan. Tilalla 0.7 lehmää/ha ja ruokinnassa ei käytettä kivennäisfosforia.

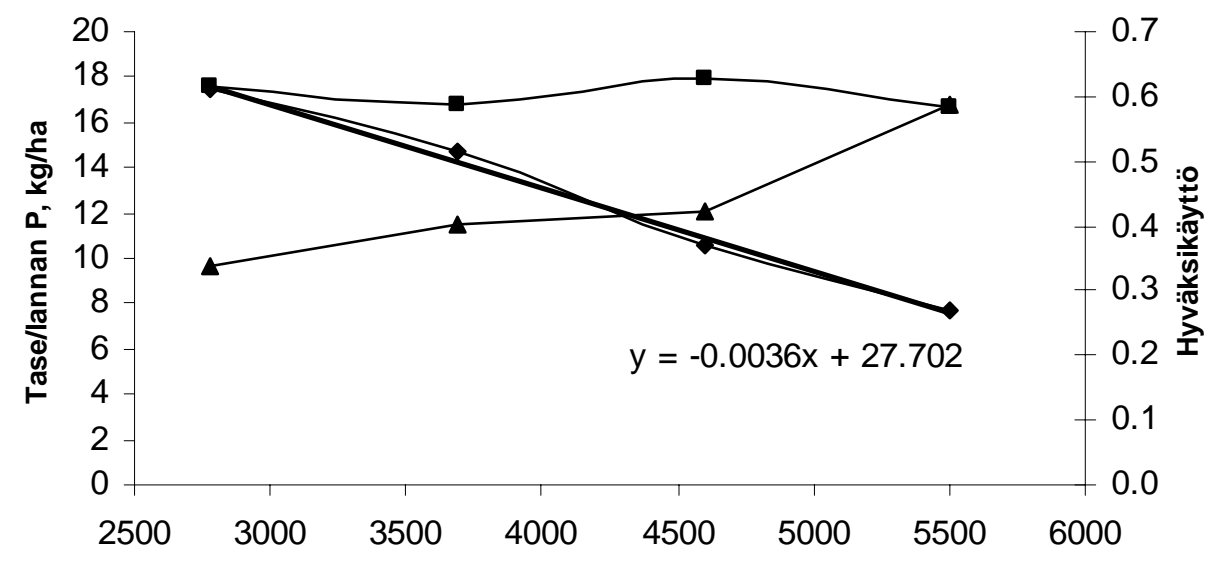

Satotaso (vilja ja nurmi keskim.), ry/ha

Kuvio 5. Simulointi pellon kasvukunnon (mallin kasvukerroin 0.6, 0.8, 1.0 tai 1.2) vaikutuksesta tilan P-taseeseen ( $\bullet$ ), lannan P-määrään ( $\bullet$ ) ja fosforin hyväksikäyttöön (tilasysteemi) ( $\boldsymbol{\Delta}$ ) kun karjan tuotostaso on $9000 \mathrm{~kg} / \mathrm{vuosi}$, rehuina käytetään säilörehua, viljaa, rypsiä ja matalafosforista $(27 \mathrm{~g} / \mathrm{kg})$ rehukivennäistä sekä ruokinnat optimoidaan maksimaalisen maitotuotto-rehukustannus erotuksen mukaan. Tilalla 0.7 lehmää/ha sekä väkilantafosforia käytettään keskimäärin 7 kg/ha.

\section{Johtopäätökset}

Tulokset osoittivat, että tutkimuksessa kehitetyllä mallilla estimoidut P- ja N-tilataseet korreloivat hyvin havaittujen tilataseiden kanssa $\left(P: \mathrm{R}^{2}=0.800\right.$ ja $\left.\mathrm{N}: \mathrm{R}^{2}=0.876\right)$. Mallilla simuloitujen että havaittujen tulosten perusteella tilalle ostettu fosforilannoitekilo lisäsi P-ylijäämää noin $1.2 \mathrm{~kg} / \mathrm{ha} / \mathrm{kg}$. Tämä johtuu todennäköisesti siitä, että ostorehujen ja lannan fosforia ei huomioida riittävästi viljeltä- 
vien kasvien lannoituksessa. Johtopäätöksenä voidaan todeta, että maitotilan kasvinviljelyn ja maidontuotannon integroiva systeemimalli on hyvin käyttökelpoinen työkalu pyrittäessä löytämään tehostamiskeinoja ravinteiden hyväksikäytölle. Jatkotutkimuksissa mallia täydennetään laidunkierrolla ja nurmirehujen korjuustrategialla.

\section{Kiitokset}

Mallin kehittäminen tehtiin osana "Suomen kotieläintalouden fosforikierto - tila- ja aluetason käytäntöjen optimointi" - hanketta, jota rahoittivat MMM, Kemira Grow-How Oyj, Valio Oy, STKL, Honkajoki Oy ja MTT. Kiitämme rahoittajia yhteistyöstä.

\section{Kirjallisuus}

ARC 1980. Agricultural Research Council. The nutrient requirements of Ruminant livestock. -Commonwealth Agricultural Bureaux and Agricultural Research Council, Farnham Royal. $351 \mathrm{~s}$.

Buysse, J., Van Huylenbroeck, G., Vanslembrouck, I. \& Vanrolleghem, P. 2005. Simulating the influence of management decisions on the nutrient balance of dairy farms. Agricultural Systems 86 (2005) 333-348

Ekholm, P, Turtola, E., Grönroos, J., Seuri, P. \& Ylivainio, K. 2005. Phosphorus loss from different farming systems estimated from soil surface phosphorus balance. Agriculture, Ecosystems and Environment, 110 (3-4): 266-278.

MMM, 2004. Horisontaalisen maaseudun kehittämisohjelman väliarviointi. Manner-Suomi. MMM:n julkaisuja 1/2004. Maa- ja metsätalousministeriö, Helsinki. ISSN 1238-2531.

MTT, 2006. Rehutaulukot ja ruokintasuositukset -verkkopalvelu. Saatavilla: www.agronet.fi/rehutaulukot. Huhtanen, P., Nousiainen., J. \& Rinne. M. 2008. Lypsylehmien rehuannoksen taloudellinen optimointi tuotosvasteiden perusteella Maataloustieteen Päivät 2008.

Huhtanen P., Nousiainen, J.I. 2006. Dynaaminen karjamalli uudistuseläinten tarpeen laskentaan. In: Toim. Anna-Maija Heikkilä. Kestävä lehmä: lypsylehmien poiston syyt ja kestävyyden taloudellinen merkitys. MTT:n selvityksiä 112: 41-47.

https://portal.mtt.fi/pls/portal/docs/PAGE/MTT/JULKAISUT/MTT_SELVITYKSIA/VK_2006_B/MTTS112.P DF Verkkojulkaisu päivitetty 2.5.2006

Nousiainen, J.I. 2006. Lypsylehmien poiston syyt. In: Toim. Anna-Maija Heikkilä. Kestävä lehmä : lypsylehmien poiston syyt ja kestävyyden taloudellinen merkitys. MTT:n selvityksiä 112: 9-26.

https://portal.mtt.fi/pls/portal/docs/PAGE/MTT/JULKAISUT/MTT_SELVITYKSIA/VK_2006 B/MTTS112.P DF Verkkojulkaisu päivitetty 2.5.2006

Rinne, M., Huhtanen P. \& Nousiainen, J. 2008. Säilörehun ja koko rehuannoksen syönti-indeksit auttavat lypsylehmien ruokinnan suunnittelussa. Maataloustieteen Päivät 2008.

Räike, A., Gralund, K. \& Ekholm, P. 2004. Maatalouden ravinnekuormitus ja sen vesistövaikutukset - arviointi seuranta-aineistojen avulla. Ravinnekuormitus. In: Eila Turtola \& Riitta Lemola (eds.). Maatalouden ympäristötuenseuranta MYTVAS 2 Osahankkeiden 2-7 väliraportit 2000-2003. Maa- ja elintarviketalous 59: 97-109. Saarela, I., Järvi, A., Hakkola, H., Rinne, K. 1995. Fosforilannoituksen porraskokeet 1977-1994. Tiedote 16/95. Maatalouden tutkimuskeskus, Jokioinen. (In Finnish with an English summary)

Salo, T., Rankinen, K., Granlund, K., Ekholm, P., Lemola, R., Esala, M. \& Räike, A. 2007. Typpikuormitus. In: Turtola, E. \& Lemola, R. (eds.) Maatalouden ympäristötuen vaikuttavuuden seurantatutkimus MYTVAS 2. Vesistökuormitus, sadon laatu ja talous. Maa- ja elintarviketalous. Käsikirjoitus.

Sharpley, A.N., Daniel, T., Sims, T., Lemunyon, J., Stevens, R., \& Parry, R. 2003. Agricultural Phosphorus and Eutrophication. 2nd ed. U.S. Department of Agriculture, Agricultural Research Service, ARS-149, 44 pp. Available at www.ars.usda.gov/np/index.html.

Uusitalo, R., Ekholm, P., Turtola, E., Rankinen, K., Granlund, K., Salo, T., Räike, A. \& Grönroos, J. 2007. Fosforikuormitus. In: Turtola, E. \& Lemola, R. (eds.) Maatalouden ympäristötuen vaikuttavuuden seurantatutkimus MYTVAS 2. Vesistökuormitus, sadon laatu ja talous. Maa- ja elintarviketalous. Käsikirjoitus.

Van Bruchem, J., Schiere, H. \& van Keulen, H. 1999. Dairy farming in the Netherlands in transition towards more efficient nutrient use. Livestock Production Science 61: 145-153.

Wattiaux, M. A. 2001. A simple model to optimize feeding programs and crop rotation of dairy farms. In: Proceedings, third conference on nutrient management challenges in livestock and poultry operations: international and national perspectives, Babcock Institute, UW-Madison, Madison, WI, 54-69.

Virtanen, H. \& Nousiainen, J. 2004. Nitrogen and phosphorus balances on Finnish dairy farms. Agricultural and Food Science in Finland 14, (2):166-180.

Yrjänen, S., Nousiainen, J.I., Kytölä, K., Khalili, H. \& Huhtanen, P. 2003. Ruokinnalliset mahdollisuudet parantaa fosforin hyväksikäyttöä maidontuotannossa. In: Jaana Uusi-Kämppä, Markku Yli-Halla ja Kaarina Grék (eds.). Lypsykarjataloudesta tulevan ympäristökuormituksen vähentäminen. Maa- ja elintarviketalous 25: 13-25. 